\title{
Re-Crafting Ornamental Display: Millie Chen's Wallpaper Intervention in Chinoiserie Decorative Design
}

\section{Michelle Veitch}

Volume 44, numéro 1, 2019

URI : https://id.erudit.org/iderudit/1062154ar

DOI : https://doi.org/10.7202/1062154ar

Aller au sommaire du numéro

Éditeur(s)

UAAC-AAUC (University Art Association of Canada | Association d'art des universités du Canada)

ISSN

0315-9906 (imprimé)

1918-4778 (numérique)

Découvrir la revue

Citer cet article

Veitch, M. (2019). Re-Crafting Ornamental Display: Millie Chen's Wallpaper Intervention in Chinoiserie Decorative Design. RACAR: Revue d'art canadienne Canadian Art Review, 44(1), 75-89. https://doi.org/10.7202/1062154ar

\section{Résumé de l'article}

Cet article examine l'une des chinoiseries de Millie Chen, l'installation wallpaper, exposée au Centre culturel canadien de Paris (2007). À travers une relecture des discours sociaux et politiques inscrits dans l'espace architectural, Chen subvertit la signification sociale et symbolique des intérieurs

domestiques en intervenant sur la production et la consommation de meubles décoratifs. En se livrant à des pratiques d'art critiques, elle interroge les histoires du colonialisme, de la diplomatie culturelle et du commerce liées à la production et à la distribution d'arts décoratifs aux dix-huitième et dix-neuvième siècles en Chine, en France et en Angleterre. Selon nous, Chen offre une relecture des discours nationalistes, des systèmes de classes et de la politique en matière de rapports entre les sexes en subvertissant les codes de la respectabilité et les débats sur la morale qui influencent la compréhension des chinoiseries au sein des États-nations et au-delà de leurs frontières. Son exploration des domaines discursifs de la représentation lui permet de reconstituer les changements spatiaux et temporels et de référencer les cultures et les idéologies translocales et transhistoriques. Cet ensemble de pratiques lui permet de réinterpréter les expositions d'art aussi bien au sein des espaces privés domestiques que dans les sites urbains publics.
Tous droits réservés @ C UAAC-AAUC (University Art Association of Canada | Association d'art des universités du Canada), 2019
Ce document est protégé par la loi sur le droit d'auteur. L'utilisation des services d'Érudit (y compris la reproduction) est assujettie à sa politique d'utilisation que vous pouvez consulter en ligne.

https://apropos.erudit.org/fr/usagers/politique-dutilisation/ 


\title{
Re-Crafting Ornamental Display: Millie Chen's Wallpaper Intervention in Chinoiserie Decorative Design
}

\author{
Michelle Veitch
}

\begin{abstract}
Cet article examine l'une des chinoiseries de Millie Chen, l'installation wallpaper, exposée au Centre culturel canadien de Paris (2007). À travers une relecture des discours sociaux et politiques inscrits dans l'espace architectural, Chen subvertit la signification sociale et symbolique des intérieurs domestiques en intervenant sur la production et la consommation de meubles décoratifs. En se livrant à des pratiques d'art critiques, elle interroge les histoires du colonialisme, de la diplomatie culturelle et du commerce liées à la production et à la distribution d'arts décoratifs aux dix-huitième et dix-neuvième siècles en Chine, en France et en Angleterre. Selon nous, Chen offre une relecture des discours nationalistes,
\end{abstract} des systèmes de classes et de la politique en matière de rapports entre les sexes en subvertissant les codes de la respectabilité et les débats sur la morale qui influencent la compréhension des chinoiseries au sein des États-nations et au-delà de leurs frontières. Son exploration des domaines discursifs de la représentation lui permet de reconstituer les changements spatiaux et temporels et de référencer les cultures et les idéologies translocales et transhistoriques. Cet ensemble de pratiques lui permet de réinterpréter les expositions d'art aussi bien au sein des espaces privés domestiques que dans les sites urbains publics.

Michelle Veitch is Associate Professor of Art History in the Department of Humanities at Mount Royal University, Calgary, Alberta. -michellehveitch@gmail.com

\section{Introduction}

This paper examines Chinese-Canadian artist Millie Chen's interventionist craft design titled wallpaper, which she produced for an exhibition in 2007 at the Canadian Cultural Centre, Paris, France. To create her installation, | fig. 1 | Chen decorated the gallery interior with a prefabricated wallpaper pattern called Cathay Pastoral Vine from US design company Stroheim and Romann Inc., which the manufacturer copies from historical chinoiserie decoration. ${ }^{1}$ The original pattern and Stroheim and Romann's replica both depict stereotypical images of Chinese men and women carrying bells and umbrellas set against a landscape of blossoming trees. Chen altered the wallpaper by adding depictions of figures drawn from various sources, including contemporary businessmen wearing religious and military headgear, French royalty and aristocrats, and British bourgeoisie.

In assessing Chen's installation, I distinguish between Chinese manufactured craft objects and European and American imitations referred to as chinoiserie. I use the terms decorative arts, ornamental design, and craft display interchangeably to describe furnishings, textiles, and pottery, although wallpaper imagery predominates in the discussion that follows. During the seventeenth century, Chinese workshops created decorative designs, including hand-painted wallpaper, which they sold to British and French merchants, who then exported these ornaments overseas. ${ }^{2}$ Throughout the eighteenth and nineteenth centuries, European manufacturers copied the patterns, incorporating their own styles and motifs into the original decoration. In more recent times, us companies such as Stroheim and Romann have reproduced historical chinoiserie designs for a small but diverse clientele. By reinterpreting prefabricated wallpaper patterns, Chen changed the symbolic and metaphorical meaning of the interior décor of the Canadian Cultural Centre, a subsidiary institution of the Canadian Embassy in France, and also of the surrounding building, which formerly served as the parlour of a nineteenth-century noble household.

Chen designed an immersive environment comprising wallpaper incorporated into the walls, doors, window frames, and radiators of the gallery space. She resituated and reoriented viewers by creating a piece that audiences walked around, thus changing their location within and perspective on the architectural interior and the scenic urban exterior landscape viewed through the windows. In adapting the room décor, Chen altered the public's experience 
1. Millie Chen, interview with the author, tape recording, Toronto, Ontario, February 24, 2007.

2. Gill Saunders, "The China

Trade: Oriental Painted Panels," in The Papered Wall: The History, Patterns, and Techniques of Wallpaper, ed. Lesley Hoskins (New York: Thames \& Hud son, 2005), 42-55; Gill Saunders, Wallpaper in Interior Decoration (New York: Watson-Guptill Publications, 2002), 11-26, 63-74.

3. Embassy of Canada in France, "Centre Culturel Canadien Paris," Government of Canada, http:// www.canada-culture.org/accueil_ home-en.html (accessed September 16, 2016).

4. Claire Bishop, Installation Art A Critical History (New York: Routledge, 2005), 48-60, 68-81.

5. Miwon Kwon, One Place After Another: Site-Specific Art and Locational Identity (Cambridge, MA: MIT Press, 2002), 11-24.; James Meyer, "The Functional Site or the Transformation of Site-Specificity," in Space, Site, Intervention: Situating Installation Art, ed. Erika Suderburg (Minneapolis: University of Minnesota Press, 2000), 25-27. For additional theories of the processes of exchange and consensus surrounding community- based site-specific projects see also: Grant H. Kester, Conversation Pieces: Community and Communication in Modern Art (Los Angeles: University of California Press, 2004), 8-10, 109-114, 129-131, 147151, 173-175.

6. Maria Elena Buszek, "Introduction," in Extra/Ordinary: Craft and Contemporary Art, ed. Maria Elena Buszek (Durham: Duke University Press, 2011), 6-7.

7. Howard Risatti, A Theory of Craft: Function and Aesthetic Expression (Chapel Hill: University of North Carolina Press, 2007), 4-9.

8. Glen Adamson, The Invention of Craft (New York: Berg, 2013), 5-6.

9. Buszek, "Introduction," 3-5; and Elissa Auther, "Wallpaper, the Decorative, and Contemporary Installation Art," in Extra/Ordinary: Craft and Contemporary Art, ed. Maria Elena Buszek (Durham: Duke University Press, 2011), 123-129.

10. Chen's mother and grandparents were from China. During World War II they fled from Chongqing, China, to a farming village in Sichuan Provence. In the 1940s, they moved to Taiwan, where Chen was born in 1962, and finally settled in Canada in 1968. Kealy Boyd, "Drawing on Memories of

Violence and Displacement," Hyperallergic.com, March 2, 2018, https:// hyperallergic.com/429348/drawing-on-memories-of-violence-and- and perception of the building on visual and sensual levels by enacting a series of spatial and temporal displacements and dislocations that shifted audiences' understandings of the overlapping historic and contemporary site embedded in the gallery architecture. Furthermore, Chen fulfilled the mandate of the Cultural Centre to coordinate contemporary Canadian art exhibitions, film screenings, music concerts, conferences, lectures, literary festivals, dance performances, and theatre productions on the premises and in affiliated locations throughout Paris and the surrounding environs. Promoting the Canadian cultural scene to various target audiences, including art professionals, school children, students, and the general public, the centre strengthens local, national, and international relations by planning collaborative programs with Canadian and French institutions, associations, and festivals. ${ }^{3}$

By situating her installation in the Cultural Centre, however, Chen engaged in a postcolonial critique that challenges how wallpaper imagery and architectural space is understood and perceived through a site-specific intervention. Site-specific art refers to works that critically assess the institutional and ideological contexts of the spaces where artists produce and exhibit their works. Art critic Claire Bishop suggests that this approach develops earlier phenomenological traditions of installation art that intervened in building sites by altering the design and layout of gallery interiors, displacing and decentring viewers so they looked at the surrounding space from multiple and shifting angles, thus changing their subjective and emotive response to architectural environs. ${ }^{4}$ Installations were adapted to varied contexts without necessarily engaging in critique; meanwhile site specific practices addressed the gallery infrastructure surrounding exhibitions. Miwon Kwon and James Meyer have also described the discursive turn in site specificity through which artists negotiate the conflicting interests and agendas of the varied organizations involved in the funding, planning, and implementation of cultural programs. ${ }^{5}$ Throughout this article, I refer to Millie Chen's 2007 exhibition project as an installation while also assessing the extent to which she developed traditions of site-specificity by either adapting or reformulating institutional histories, policies, and mandates.

In examining the ways Chen used practices of criticality to reinterpret the Canadian Cultural Centre, I argue that her wallpaper intervention intersects with craft scholarship that examines the material, technique, and form of objects, and analyses the social and political function, meaning, and context of decorative arts. ${ }^{6}$ In reviewing this critical literature, Howard Risatti assesses the ontological and epistemological discourses surrounding modernist traditions that separate fine art and decorative design into opposing categories of high and low culture, hence reinforcing hierarchical systems of interpretation and evaluation. ${ }^{7}$ Glen Adamson argues that craft objects and practices displace such modernist paradigms, and "keep pressing questions of form, category, and identity open for further investigation." 8

As a contemporary craft practitioner, Chen addresses feminist and postcolonial theories that explore racialized, sexualized, and gendered identities marginalized and suppressed in modernist art discourse. ${ }^{9}$ Her studio practice is further informed by her own background as an artist of Chinese ancestry who was born in Taiwan and immigrated with her family to Canada as an 


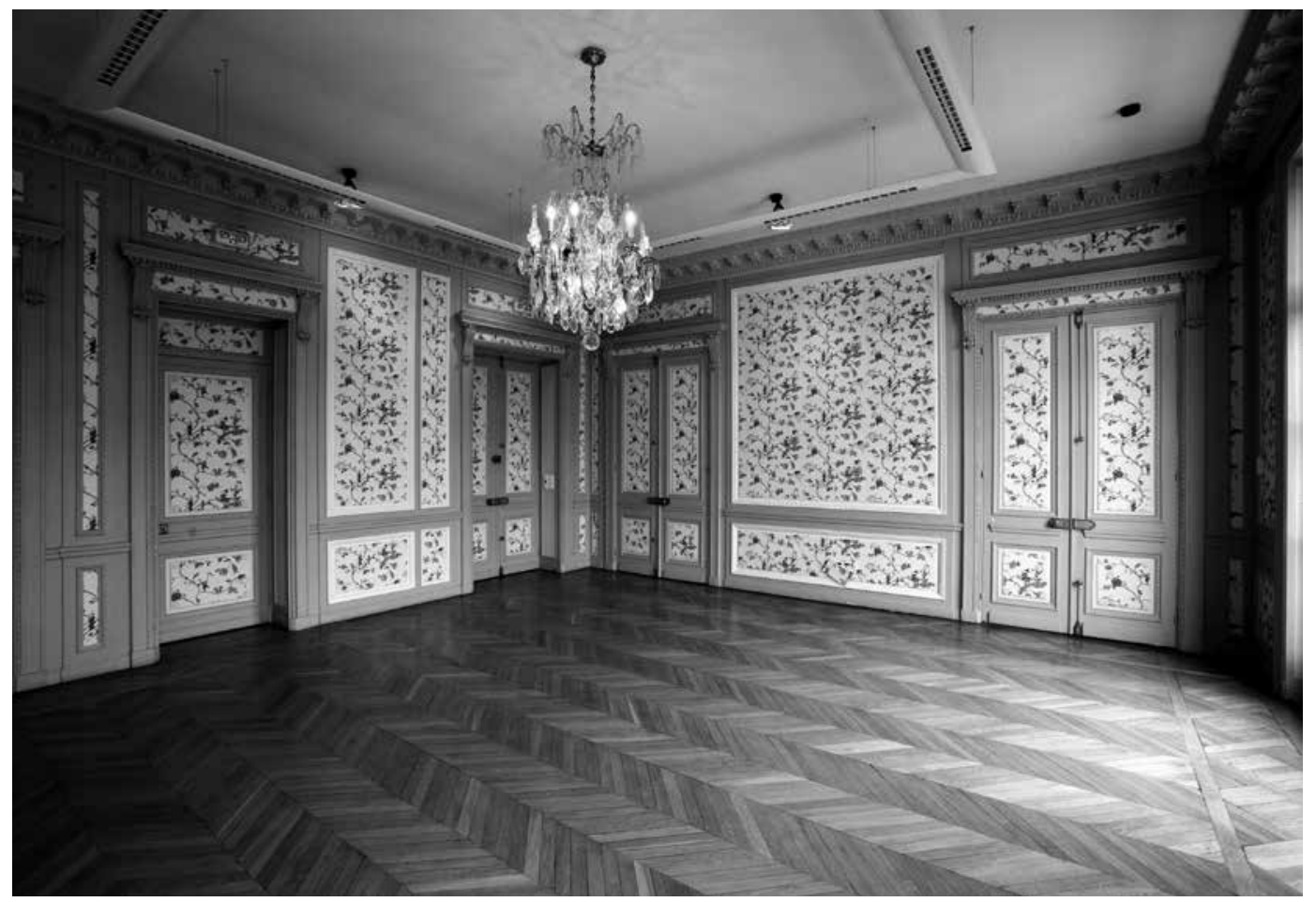

Figure 1. Millie Chen, wallpaper, 2007. Found wallpaper (Cathay Pastoral Vine, Stroheim \& Romann Inc.), acrylic paint and ink. Canadian Cultural Centre, Paris, France. Photo: Didier Morel, 2007. Collection of the artist, Rideway, Ontario, Canada.

displacement/ (accessed October 17, 2018).

11. Johanna Drucker, "Affectivity and Entropy," in Objects and Meaning: New Perspectives on Art and Craft, eds. M. Anna Fariello and Paula Owen (Lanham, MD: Scarecrow Press, 2004), 141-144. infant, where she now lives while working in the United States. ${ }^{10}$ Her own family history and experience of diasporic travel and migration complicates the interpretation of her installation, which references transnational trade and tourism. While revisionist theories redress the omissions underlying contemporary craft, including identities of cultural alterity and hybridity as exemplified in Chen's wallpaper design, many scholars often re-inscribe existing dichotomies by subsuming craft to conceptually-driven art practices that engage in institutional critique. In discussing conceptually-based approaches, Johanna Drucker describes practices of "negative and affirmative criticality" that deconstruct, question, and interrogate institutional standards used to assess and evaluate art making while transforming and changing the structure, organization, and properties of cultural objects including their emotive, sensorial, and subjective qualities and meanings. ${ }^{11}$

Critical literature that examines the conceptual and theoretical meanings and processes underlying craft informs my understanding of Chen's wallpaper installation on two counts. First, her hand-painted images on prefabricated decoration (which introduce specialized techniques to mass-produced ornamentation) reinterpret the aesthetic hierarchy that separates craft, commercial design, and art. Second, Chen incorporates painted images into the wallpaper design using wit and satire to parody the social and economic classes that participated in colonial conquest and capitalist markets in China, France, and Britain from the eighteenth century onward. Employing humorous devices, she inverts chinoiserie design which she suggests "represent $[s]$...this 
12. Chen, interview with the author.

13. Ibid.

14. The architect, Alfred Coulomb, constructed the building in 1889 for Louis-Emmanuel, vicomte d'Harcourt-Olonde, his sister Mlle Pauline d'Harcourt, and her husband, Gabriel Paul Othenin de Cléron, comte d'Haussonville. François Lucbert, "La Promotion des Arts Visuels: au Centre Cultural Canadien de Paris," Vie des Art 43, no. 175 (Summer 1999): https:// www.erudit.org/fr/revues/va/1999v43-n175-va1135956/53124ac.pdf (accessed February 15, 2018) fantasy folly world... that...speaks volumes about the culture from which it originates, not the one that it purports to represent." ${ }^{12}$ Engaging in acts of "playful subversion" and "gentle interrogation," ${ }^{13}$ she critically intervenes in the visual landscape of fantasy and folly by reflecting back on the colonial cultures through which such decorative ornamentation was interpreted and appropriated. Reimaging and reinventing stylized patterns that are imitations of an imitated style, she reveals the ways that wallpaper design functions as mimicry and mimesis to reflect and project the political and historical legacies of imperialism that opened up commerce and trade abroad, eventually leading to the expansion of global market economies in the present day.

By re-envisioning interior decorative display, Chen re-contextualized the contemporary function of the Cultural Centre as well as its historical function as an hôtel particulier for the nobility. ${ }^{14}$ The Cultural Centre's gallery was formerly a parlour-the most public room of an upper-class mansion-once decorated in lavish décor that declared the social status of its occupants. Chen excavated the genealogy of the site by recreating a historic domestic interior in the contemporary gallery setting, thus redefining the architectural space and the urban neighbourhood surrounding it-the Esplanade des Invalides in the 7 th Arrondissement of Paris. The Esplanade memorializes France's military history and includes the Hôtel des Invalides, which houses Napoleon Bonaparte's tomb, a military museum, and a residence and hospital for war veterans. These monuments and museum document French colonialism in Europe, Africa, and Asia, and hence project histories of military conquest into the surrounding city district. Chen, on the other hand, explores conflicting cultural icons and emblems that undermine such narratives of empire building. Interrupting the material production and consumption of interior décors and gallery displays, she reformulates the aesthetic traditions and exhibition practices of wallpaper design, engaging with theories of site-specificity, institutional critique, and the ideological discourses addressed in intersecting craft and art scholarship.

The next section of this paper examines Chen's wallpaper installation in relation to narratives of decorativeness, domesticity, and femininity, focusing on the codes of decorum and respectability that defined chinoiserie display in the ancien régime and revolutionary France, and during the reign of Queen Victoria in England. While Chen's exhibition redresses such craft histories, her work takes on another layer of meaning in the contemporary gallery space of the Canadian Cultural Centre, a site that has its own fraught history as a subsidiary of the Canadian Embassy and emblem of the nation-state and its policies of nationalism, liberalism, and tourism. I argue that her project is complicated by the administrative and governmental mandates that define exhibitions and public programs at the Cultural Centre, thereby raising questions about the efficacy and viability of her craft-based, site-specific practices in the institutional framework of the gallery organization and the Canadian consulate with which it is affiliated.

\section{Luxury Splendour, Moralist Discourses, and Classed Aesthetics} Although I was not able to visit Chen's exhibition at the Canadian Cultural Centre, I consulted journal articles, gallery catalogues, and recorded an interview with the artist in order to understand Chen's work. In the interview, Chen 
15. Saunders, Wallpaper in Interior Decoration, 11-26.

16. Jonathan D. Spence, The Search for Modern China, 2nd ed. (New York: W.W. Norton \& Company, 1999), 133-134; Ina Baghdiantz McCabe, Orientalism in Early Modern France: Eurasian Trade, Exoticism, and the Ancien Régime (Oxford: Berg Publishers, 2008), 286-289.

17. Dawn Jacobson, Chinoiserie (London: Phaidon, 1999), 61-82.

18. Ibid.

19. Chen, interview with the author.

20. Ibid.

21. Dale K. Van Kley, The Religious Origins of the French Revolution: From Calvin to the Civil Constitution, 1560-1791 (New Haven, ст.: Yale University Press, 1996), 135-190.

22. Nicholas Dew, Orientalism in Louis XIV's France (New York: Oxford, 2009), 141, 144, 205-206; Spence, Search for Modern China, 133-134. identified the figures and costumes that she depicted in her wallpaper design and the varied sources on which she drew. She also described the themes of imperialism, hybridity, and cultural embodiment she addressed in her installation. In what follows, I describe the history of Chinese ornaments and chinoiserie decorations in eighteenth and nineteenth-century France and England focusing on competing discourses of decadence, luxury, and splendour through which ornamental displays were evaluated and assessed in order to provide an analytical and theoretical background to explain the cultural and political meanings of Chen's wallpaper installation.

According to Gill Saunders, British and French trading companies began exporting Chinese craft to London and Paris in the early seventeenth century under the restrictions of the Chinese government. ${ }^{15}$ Jonathan Spence describes how French royalty funded Jesuit priests to travel to China in the seventeenth and eighteenth centuries where they recorded examples of regional craft in their diaries and journals. In order to monopolize craft production and consumption, the French monarchy instituted sumptuary laws and controlled state trading and manufacturing companies that sold imported luxury goods, including Chinese wares and chinoiserie imitations, to the French nobility and aristocracy. ${ }^{16}$ By the mid-eighteenth century, French merchants had opened up global markets and expanded their customer base to include the bourgeoisie and the middling elites. Consumers believed that they fulfilled a moral obligation and bolstered the national economy by purchasing imported crafts and French manufactured decorative arts. Following this trend, French patrons incorporated chinoiserie into their residences, including King Louis xv (r. 1715-1774), Queen Marie Leszczyńska (r. 1725-1774), the King's mistress, Madame de Pompadour, aristocrats such as the Duchesse de Berry and the Duc d'Orléans, and middling elites like Edmé-François Gersaint and Lazare Duvaux. ${ }^{17}$ However, political sentiments changed following the Revolution in 1789. The general populace decried the corruption and immorality of a royal court and aristocracy engaged in lavish and reckless spending. ${ }^{18}$

It is precisely these shifting discourses of respectability that Chen addressed in her wallpaper installation at the Canadian Cultural Centre, referencing changing political economies and class systems in the cultural exchange of luxury goods and decorative designs. In discussing her work, Chen indicated that she painted a man wearing a contemporary business suit and a mitre hat, ${ }^{19} \mid$ fig. 2 | such as French bishops wore in the seventeenth and eighteenth centuries. ${ }^{20}$ During this period, the Gallican Church came under the control of the King of France who claimed certain privileges, such as the right to appoint bishops and to review and register decrees coming from the Roman Papacy. ${ }^{21}$ Expanding his jurisdiction over religious orders, King Louis XIV (r. 1643-1715) supported the activities of Jesuit priests and patronized their travels to China, which preceded colonial conquests in the area and opened up commerce and trade. ${ }^{22}$ By conflating politically-appointed religious leaders and corporate business classes, Chen explores the intersection of Catholicism, imperialism, and capitalism from the past to the present day.

In addition to identifying religious and business figures in her work, Chen also described how she depicted French royalty, copying Jean Honoré Fragonard's oil painting, The Swing (1767), | fig. 3 | which shows the aristocracy 
Figure 2. Millie Chen, wallpaper (detail), 2007. Found wallpaper (Cathay Pastoral Vine, Stroheim \& Romann Inc.), acrylic paint and ink. Canadian Cultural Centre

Paris, France. Photo: Didier

Morel, 2007. Collection of the artist, Rideway, Ontario, Canada.
Figure 3. Millie Chen, wallpaper (detail), 2007. Found wallpaper (Cathay Pastoral Vine, Stroheim \& Romann Inc.), acrylic paint and ink. Canadian Cultural Centre,

Paris, France. Photo: Didier

Morel, 2007. Collection of the artist, Rideway, Ontario, Canada.
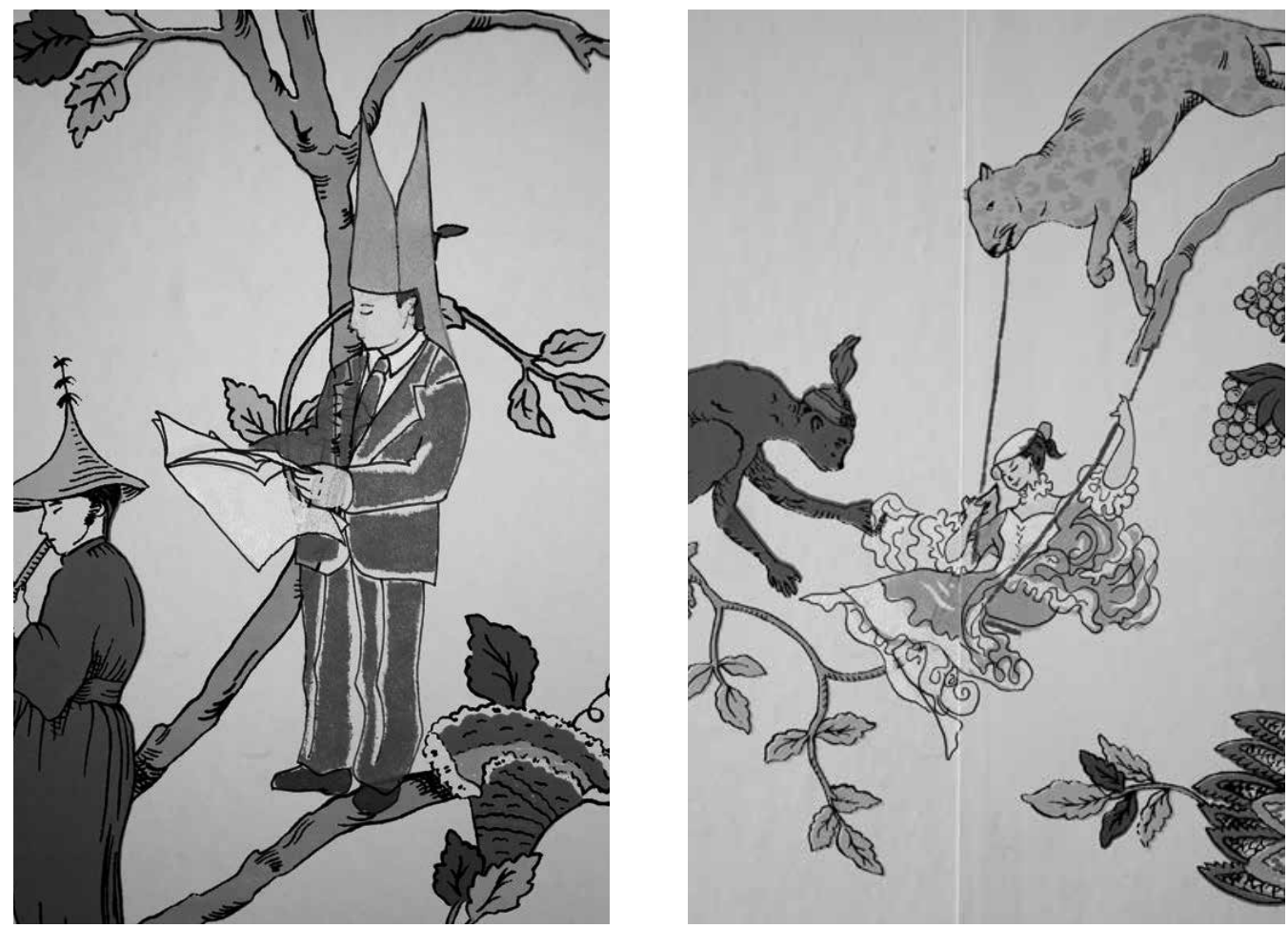
23. Chen, interview with the author.

24. Ibid.

25. The French poet Charles Collé indicated in his personal writings that Fragonard created The Swing for an unnamed gentleman of the court. See Jennifer Milam, "Playful Constructions and Fragonard's Swinging Scenes," Eighteenth Century Studies 33, no. 4 (2000): 549

26. Chen, interview with the author.

27. Baghdiantz McCabe, Orientalism in Early Modern France, 273-275.

28. Spence, Search for Modern China, 163 .

29. Ibid., 220, 229.

30. Alison McQueen, "Power and Patronage: Empress Eugénie and the Musée Chinois," in Twenty-First-Century Perspectives on Nineteenth-Century Art: Essays in Honor of Gabriel P. Weisberg, ed. Gabriel P. Weisberg, Petra D. Chu, and Laurinda S. Dixon (Newark, N): University of Delaware Press, 2008), 153-161; Ting Chang, "Equivalence and Inversion: France, Japan, and China in Goncourt's Cabinet," in Travel, Collecting, and Museums of Asian Art in Nineteenth-Century Paris (Burlington, $\mathrm{vT}$ : Ashgate, 2013), 121-123, 127-140. frolicking in a forest glade. ${ }^{23}$ She freeze-framed a woman pushing her body forward on a swing held in place by a rope dangling from a leopard's mouth. Chen created an erotically-charged scene by placing the figure beside the disturbing image of an oversized monkey lifting up the woman's dress. ${ }^{24}$ Such exotic animal imagery reveals the primitivist fantasies perpetuated by European designers who likened chinoiserie to curiosity displays that evoked both delight and horror in viewers. By juxtaposing exotic animals with symbols of royalty, Chen alludes to the discourses of moral decadence used to characterize chinoiserie design and the aristocracy who decorated their residences with such ornamentation. She reveals the pejorative interpretations projected onto art produced by and for the ruling class such as Fragonard's The Swing, which was commissioned and exhibited by the nobility and represented the aesthetics of the French court. ${ }^{25}$

Chen further explained that she engaged in playful acts of subversion by depicting Marie Antoinette with her infamous pouf hairstyle and "pannier" dress, which she contrasts with a picture of a modern businessman wearing the Girondist and Napoleon hats of the revolutionaries ${ }^{26}$ who overthrew the monarchy and, in so doing, reformed cultural aesthetics by deriding the court and aristocracy as excessive in their tastes. Ina Baghdiantz McCabe argues that these critics disparaged women of the nobility who delighted in the sensuous pleasures of orientalist décor and exhibited what the public perceived as lascivious behaviour. ${ }^{27}$ Discourses on respectability shaped perceptions of decorative furnishings and textiles that the general populace devalued because they believed the goods symbolized female indulgence, which threatened the moral fabric of French society.

In referencing changing classed aesthetics surrounding chinoiserie during the Revolution, Chen alludes to a historical era that saw the expansion of France under the First (1792-1804) and Second (1848-1852) Republics, and the constitutional monarchy (1814-1848). During this period, France went to war with China in order to expand its influence in the region, eventually gaining trade and land rights through the Treaty of Wampoa (1844) that granted France limited territorial and economic jurisdiction in China. ${ }^{28}$ In addition, France conquered Annam, Cambodia, Cochin, Tonkin, Laos, Yunnan, Guangxi, Guangdong, the island of Hainan, and acquired a leasehold on the Chinese region of Kwangchowan. ${ }^{29}$ However the Chinese government curtailed French commercial activities in China, resulting in increased tensions between the two states. Despite mounting hostilities overseas, French patrons continued to decorate their homes with Chinese furnishings and chinoiserie imitations. For instance, the Empress Eugénie, wife of Napoleon III of the Second French Empire, created the Musée Chinois (built 1860-1861) at the palace of Fontainebleau while French art dealers and critics Edmond de Goncourt, August Sichel, Henri Cernuschi, and Albert Jacquemart all collected, displayed, and sold Chinese craft in their homes and/or commercial shops. ${ }^{30}$

Chen alludes to French decorative manufacture and trade during periods of colonial expansion by showing figures dressed in costumes that combine contemporary business suits with revolutionary clothing, hence tracing a lineage from historical political factions to the modern merchant classes who gained in stature following the founding of the First Republic and 
31. David Beevers, “'Mand'rin Only is the Man of Taste': 17 th and 18th-Century Chinoiserie in Britain," in Chinese Whispers: Chinoiserie in Britain, 1650-1930, ed. David Beevers (Brighton, UK: Royal Pavilion \& Museums, 2008), 17-19; Jacobson, Chinoiserie, 126, 134, 138-141, 146-149.

32. Spence, Search for Modern China, 120-123, 127-130, 154-160, 180-183.

33. Ibid., 160-166, 180-183.

34. Patrick Conner, "Chinese Style in 19th Century Britain," in Chinese Whispers: Chinoiserie in Britain, 1650-1930, ed. David Beevers (Brighton, UK: Royal Pavilion \& Museums, 2008), 65-66, 68; Jacobson, Chinoiserie, 187-195.

35. Sarah Cheang, "Selling China: Class, Gender, and Orientalism at the Department Store," Journal of Design History 20, no. 1 (2007): 4-7.

36. Anne Anderson, "Coming Out of the China Closet?: Performance, Identity and Sexuality in the House Beautiful," in Oriental Interiors: Design, Identity, Space, ed. John Potvin (London: Bloomsbury, 2015), 133-140; Sarah Cheang, "Dragons in the Drawing Room: Chinese Embroideries in British Homes, 1860 1949," Textile History 39, no. 2 (2008) 231-236; Stacey Sloboda, "Making China: Design, Empire, and Aesthetics in Britain, 1745-1851" (PhD diss., University of Southern California, 2004), 300-302, 309-322.

37. Cheang, "Dragons in the Drawing Room," 231-236.

38. Chen, interview with the author.

39. Ibid. the expansion of the French Empire. Chen's installation also references craft patronage in England by depicting the clothing of British bourgeois women, thus representing another class of consumers who purchased chinoiserie ornaments. British patrons incorporated Chinese furnishings into their residences throughout the eighteenth century, including the Duke of Argyll and Lord Verney, the social reformer Elizabeth Montague, actor David Garrick, and naval officer Commodore Anson. ${ }^{31}$ To facilitate international exchange, China allowed the British East India Company (BEIC) to increase trade in opium, silk, tea, porcelain, and decorations under the Cohong system from 1750 until the mid-nineteenth century when it began to restrict drug trafficking operations, resulting in the First Opium War (1839-1842) and the Second Opium War (1856-1860). ${ }^{32}$ The wars concluded with the Treaties of Nanking (1842) and Tientsin (1858), respectively, by which China ceded Hong Kong to Britain (expanded in 1860 to include parts of mainland Kowloon). The treaties also abolished the Cohong system, opened up multiple seaports, granted British residences in designated cities, and allowed foreigners extended travel. China nevertheless resisted the treaty provisions by restricting British residency status and maintaining a monopoly on market activities. ${ }^{33}$ Throughout these conflicts, British patrons continued to purchase chinoiserie decorations, including King George Iv (r. 1820-1830) who incorporated them into Carlton House, London (built ca. 1783-1790), and the Royal Pavilion at Brighton (built ca. 1802-1822). ${ }^{34}$ Sarah Cheang shows that manufacturers also sold imported Chinese craft ware in both upscale and mass department stores, reaching a wide range of customers. ${ }^{35}$

Reassessing the discontinuous and fragmented history of patronage surrounding decorative arts, Chen re-interprets gendered narratives of luxury and decadence informing understandings of ornamental furnishings in Victorian England. Stacey Sloboda suggests that working and middle-class British women consumed chinoiserie ceramics and drank tea in order to declare their Englishness and fulfill their moral and nationalist obligations. By contrast, Anne Anderson and Sarah Cheang argue that upper-middle-class men distinguished their collections of Chinese ware and chinoiserie imitations from feminine decorative bric-à-brac by creating beautiful and sumptuous interior designs that reflected the refined aesthetic tastes and elevated cultural standards of the male connoisseur. ${ }^{36}$ Further, their collections served as memorabilia of travels to China and their participation in British colonial schemes, mercantile relations, and cultural diplomacy. ${ }^{37}$

Critical theories of the moral and classed aesthetics underlying chinoiserie craft provide an analytical framework for assessing Chen's wallpaper design, which explores the shifting iconographic meanings of ornamental display in England. In discussing how she changed and adapted wallpaper patterns, Chen points out a Victorian mourning gown |fig. $4 \mid$ that became fashionable in Britain during the nineteenth century, ${ }^{38}$ which she depicts upon a pre-existing Chinese figure of ambiguous gender. ${ }^{39}$ Queen Victoria (r. 1837-1901) initiated the trend for mourning dress following the death of her husband, Prince Albert (1819-1861), whom she honoured by wearing black for the remainder of her life. Following the Queen's example, widows curtailed social engagements and wore funeral clothing out of loyalty to their deceased 
Figure 4. Millie Chen, wallpaper (detail), 2007. Found wallpaper (Cathay Pastoral Vine, Stroheim \& Romann Inc.), acrylic paint and ink. Canadian Cultural Centre,

Paris, France. Photo: Didier

Morel, 2007. Collection of the artist, Rideway, Ontario, Canada.
Figure 5. Millie Chen, wallpaper (detail), 2007. Found wallpaper (Cathay Pastoral Vine, Stroheim \& Romann Inc.), acrylic paint and ink. Canadian Cultural Centre,

Paris, France. Photo: Didier

Morel, 2007. Collection of the artist, Rideway, Ontario, Canada.
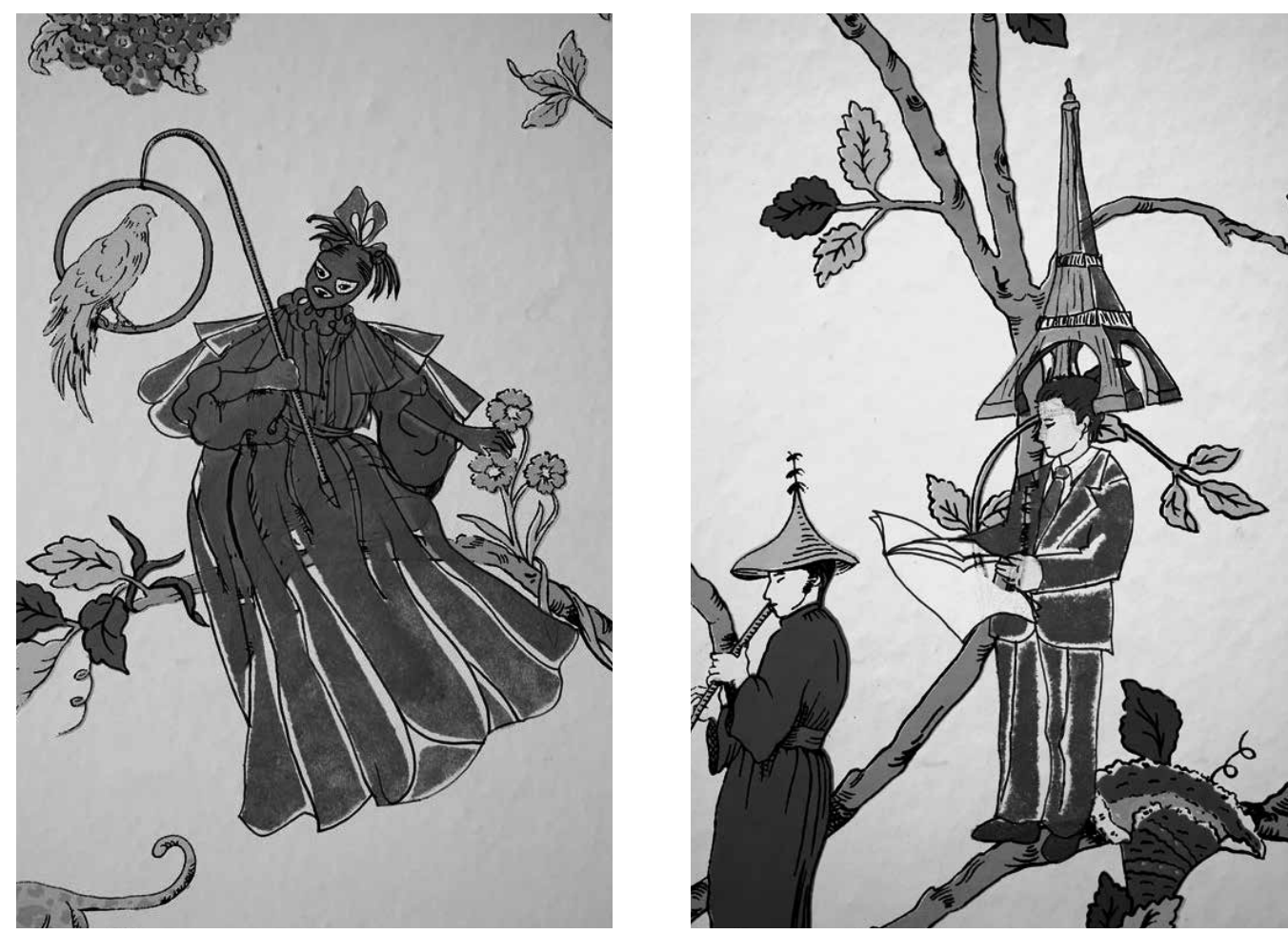
40. Sonia A. Bedikian, "The Death of Mourning: From Victorian Crepe to the Little Black Dress," Journal of Death and Dying 57, no. 1 (2008): 40-43.

41. Chen, interview with the author

42. Ibid.

43. Sloboda, "Making China," $42-55,306,318-322$

44. Philip Howell, "Race, Space and the Regulation of Prostitution in Colonial Hong Kong," Urban History 31, no. 2 (2004): 233-234 241-244; Spence, Search for Modern China, 207-208.

45. Chen, interview with the author spouses. ${ }^{40}$ Through her placement of the mourning dress, Chen reinterprets the original wallpaper decoration, which depicted stereotypical images of feminized Chinese males in red jackets and blue pants. ${ }^{41}$ By changing their clothing, she subverts masculine and feminine ideals and the gendered and racialized discourses embedded in nineteenth-century British interior displays. Furthermore, she pushes the transgressive potential of craft design and plays with concepts of the "masquerade" by combining multiple and shifting identity markers into bricolage patterns that confuse and collapse cultural and gendered stereotypes.

In a wry twist of humour, Chen adds an S\&M leather mask over the face of the figure wearing the Victorian mourning dress. ${ }^{42}$ By depicting s\& $\mathrm{M}$ gear, Chen references sexual fantasies and identities that would have exceeded the bounds of Victorian acceptability, drawing attention to the morality discourses inherent in chinoiserie decoration. Critics believed that ornamentation overstimulated the visual and bodily senses and threatened the dictates of restraint and austerity governing Victorian aesthetic traditions..$^{43} \mathrm{It}$ is precisely this moral prudishness that Chen alludes to in her images of sexual lasciviousness and impropriety, subverting the carefully ordered and structured home interiors that reflect the supposed puritan values of the British Empire. Thus, Chen hints at the hypocrisy of Victorian social elites who reinforced strict ethical standards in England while engaging in colonial conquests abroad that granted jurisdiction over the drug and sex trades in imperial outposts. While overseas, British expatriates visited opium dens, kept Chinese mistresses, and hired sex workers, eschewing the codes of decorum they adhered to in their home country ${ }^{44} \mathrm{Chen}$ alludes to the repressed underside of English society and references the double lives of Victorian moralists by masking the figures depicted in chinoiserie wallpaper and obscuring their identities.

Depicting various period costumes, Chen contrasts court fashion with populist attire to signify shifting consumer trends in ornamental furnishings between the eighteenth and nineteenth centuries in France and Britain. It is significant to note in this regard that her exhibition combined print design, court painting, textile craft, and graphic illustration, thus breaking down the boundaries separating high and low culture. Her installation exemplifies critical craft by interrogating the class systems and gendered ideologies that shaped decorative arts in home interiors. Subverting the semantic field of representation through which Chinese ware and chinoiserie imitations were encoded and decoded in accordance with dictates of social refinement and distinction, Chen redefines the cultural and political meanings and histories of craft materials, functions, and processes. She draws on feminist and postcolonial theories to reinterpret design display and adapts strategies of criticality to excavate the contending genealogies and topographies embedded in the environs where she creates her work.

In discussing her exhibition, Chen indicated that she de-contextualizes and re-contextualizes historic chinoiserie wallpaper by depicting a modern-day businessman wearing an Eiffel Tower hat, thus placing her installation in the present-day gallery site and in the surrounding district. ${ }^{45} \mid$ fig. $5 \mid$ Resituating the architectural interior in relation to the exterior urban landscape, she repositions and reorients the viewers in the building by enacting a series 
Figure 6 (below). Millie Chen, wallpaper (detail), 2007. Found wallpaper (Cathay Pastoral Vine, Stroheim \& Romann Inc.), acrylic paint and ink. Canadian Cultural Centre, Paris, France. Photo: Didier Morel, 2007. Collection of the artist, Rideway, Ontario, Canada. of perceptual and perspectival displacements. Reimagining modes of visualization perpetuated through exoticized craft display in colonialist interiors, Chen depicts a woman who looks through her camera out into the gallery space, hence mirroring the patrons who view the wallpaper installation. ${ }^{46}$ | fig. 6 | Discussing the audiences of her exhibition, she suggests that she was interested in practices of cultural embodiment that encompass “... day to day body language ... how we dress the body up ... the public face of the body, the public inscription, private rituals ... [W]e [are] conditioned to move through identity ... and to handle our body in a certain way and that is very culturally based." 47 Blurring the boundaries between the seeing subject and the viewed other in gallery exhibitions and cultural collective settings, Chen intervenes in acts of embodiment and identifica-

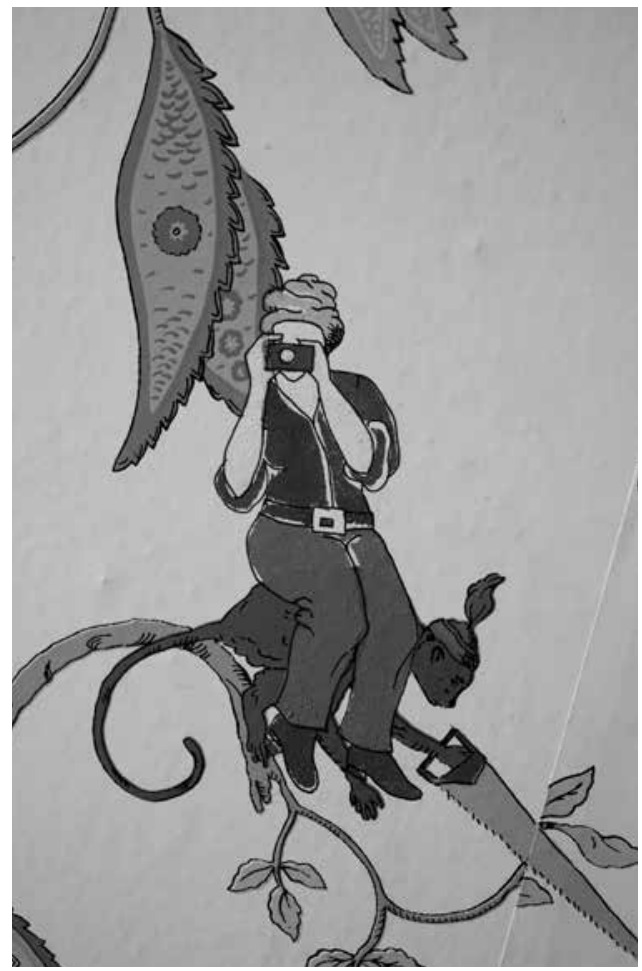

tion that mark out ethnic and racial differences through practices of looking and seeing. Whereas imperialist decorative furnishings presented Chinese people and places as immanent and knowable, Chen engages in prankish humour by painting images of anarchic figures that disassemble the pictorial scheme embedded in ornamental wallpaper designs. She depicts a boy and a monkey sawing at the vine and trellis that support other figures. They threaten to collapse the background scenery of the illustrated vignettes and interrupt the constructed narratives represented through the interior décor. ${ }^{48}$ This rebellious act extends to include modes of cultural hybridity and alterity that Chen herself embodies as a diasporic artist who references the history of transnational travel and migration surrounding craft production and version, she re-enacts a series of spatial and temporal shifts by exploring the visual and cultural paradigms through which pictorial images have been understood and perceived in different historical periods and geographic regions. consumption. Engaging in practices of playful sub-

\section{Imperial Spaces, Postcolonial Critique, and Wallpaper Interventions}

In this final section I draw on contemporary literature on diasporic interiors, craft ornamentation, and wallpaper design to explain the thematic content, socio-economic context, and methodological framework of Chen's wallpaper installation. More specifically, I address theories of orientalism developed by Edward Said, who examines the material production of knowledge in the historical context of imperialism in Arab and Islamic nations. He suggests that

46. Ibid.

47. Ibid.

48. Ibid.

49. Edward Said, Orientalism (New York: Vintage Inc., 2003), 1-31. First published 1979 textual and historical scholarship, as well as and literature and visual culture, perpetuate colonial power structures by making an epistemological and ontological distinction between the "Occident" (Western nations) and the "Orient" (all nations perceived as outside of and culturally inferior to Western civilization).$^{49}$ In authorizing representations of the "Orient," Western writers and 
50. Ibid., 1-31.

51. Stacey Sloboda, Chinois-

erie: Commerce and Critical Ornament in Eighteenth-Century Britain (Manchester: Manchester University Press, 2014), 10.

52. For further discussion of how "orientalist" interiors function as hybrid spaces by intersecting and overturning political and economic systems see John Potvin, "Inside Orientalism: Hybrid Spaces, Imaginary Landscapes, and Modern Interior Design," in Oriental Interiors: Design, Identity, Space, ed. John Potvin (London: Bloomsbury, 2015), 1-17.

53. Sara Ahmed, Queer Phenomenology: Orientations, Objects, Others (Durham, NC: Duke University Press, 2006), 150. For additional literature on textual and visual interventions in imperialist narratives see also Julie F. Codell and Dianne Sachko Macleod, "Orientalism Transposed: The 'Easternization' of Britain and Interventions in Colonial Discourse," in Orientalism Transposed: The Impact of the Colonies on British Culture, ed. Julie F. Codell and Dianne Sachko Macleod (Aldershot, uK: Ashgate, 1998), 1-10.

54. Courtney Tanner Wilder, "Staging Display in the Sculptural Work of Yinka Shonibare MBE" (Master's thesis, University of California, 2011), 77-97; Yinka Shonibare, "Setting the Stage: Yinka Shonibare $\mathrm{MBE}$ in Conversation with Anthony Downey," in Yinka Shonibare MBE, ed. Rachel Kent (Sydney: Museum of Contemporary Art; Munich: Preste Verlag, 2008), 39; and Huey Copeland, Bound to Appear: Art, Slavery, and the Site of Blackness in Multicultural America (Chicago: University of Chicago Press, 2013), 153-193.

55. Hou Hanru, "Michael Lin, Public Artist," in Michael Lin, eds. Ju dith Penner and Krystina Stermole (Ostfildern, Germany: Hatje Cantz; Vancouver: Vancouver Art Gallery, 2010), 27-34.

56. Hungry Ghost Rubric (1996) comprised a wallpaper installation that incorporated arabesque designs. The ornamental patterns symbolically represented the lashing tongue of the fabled character Demon Girl from popular Chinese folklore. In addition, Chen included the medicinal herb dang gui in the wallpaper, which emitted a pungent odour into the surrounding gallery space. Millie Chen, "Hungry Ghost Rubric," Milliechen.com, http:// milliechen.com/hungryghost.html (accessed February 20, 2015); San- academics spoke on behalf of what was perceived as the cultural other, and in so doing perpetuated stereotypes of Arab and Islamic nations as exotic, sensual, and dangerous. Western constructs of orientalism were further made to appear natural and inevitable, and employed tropes of veracity and truth in order to obscure strategic formulations through which dominant discourses were circulated and disseminated. Said argues that orientalist discourses and knowledge are inherently political and reflect the effects of imperial power that are enacted intertextually within and across academic disciplines on social, cultural, and intellectual levels. ${ }^{50}$

Said's theories can illuminate how Chen's wallpaper installation reinterpreted the historical function of the Canadian Cultural Centre as an "orientalist" interior reflecting the classed tastes and aesthetics of the French and British aristocracy, nobility, and middling elites. However, colonialist decorative design, as reimagined in Chen's installation, takes on multiple and conflicting meanings. Hence, I diverge from Said who argues that textual and historical scholarship re-inscribe imperial knowledge and power. Unlike Said, who examined Western constructs of "orientalism" imposed on Arab and Islamic cultures, I assess Chen's installation in relation to craft manufacture and distribution within and across China, France, and England during periods of colonial expansion in the eighteenth and nineteenth centuries.

In assessing decorative designs, I develop Stacey Sloboda's concept of "critical ornament," which refers to the "production, materiality and specific qualities of objects and their spatial and social contexts." ${ }^{51}$ Examining the practices, histories, and politics shaping the techniques, properties, and manufacture of colonialist décor, I expand theories of critical craft that explain how ornamental displays recodify and reauthorize hegemonic discourses of imperialism. ${ }^{52}$ Extending this line of critical enquiry, Sarah Ahmed argues that "orientalist" homes function as diasporic spaces by interrupting the social inheritance of whiteness and redefining concepts of self and other, near and far, the "Orient" and the "Occident." ${ }^{53}$ This analytic framework explains how Millie Chen's site-specific installation reimagines diasporic spaces and histories by exploring shifting subjective and objective perspectives and interpretations of the building interior and exterior, the past and the present, and the local and the global. In redefining colonialist décor, she adapts traditions of critical aesthetics developed by African-British artist Yinka Shonibare in his exhibition, The Victorian Philanthropist's Parlour (19961997) displayed at the Johannesburg Biennale (1997), and African-American artist Renée Green in her exhibition Mise en Scène (1991-) displayed at London's Institute of Contemporary Art (1991) and Philadelphia's Fabric Workshop and Museum (1992). Recreating domestic interiors decorated with wallpapers that respectively incorporate images of black soccer players and the transnational slave trade, Shonibare and Green each critique colonialist museum displays that fetishize and exoticize black bodies, hence interrupting the discursive visual and textual representations through which African diasporas are imagined in gallery exhibitions. Each depicts images of the primitivized and spectacularized "ethnic other" in order to expose the repressed racialized histories and politics underlying the circulation and distribution of ornamental decoration within and across nation states and art institutions. ${ }^{54}$ 
dra Firmin, "Sensory Navigation," in Millie Chen: Extreme Centre, exh. cat., Centre Culturel Canadien and WharfCentre d'art contemporain de Basse-Normandie (Paris: Centre Culturel Canadien; Ville Hérouville Saint-Clair, BN: WharfCentre d'art contemporain de Basse-Normandie, 2009), n.p.; Peter White, "Hungry Ghost Rubric," in Hungry Ghost Rubric, ed. Paddy O'Brien, exh. cat. Oakville Galleries (Oakville, on: Oakville Galleries, 1997), n.p.

57. White, "Hungry Ghost Rubric," n.p.; Sandra Firmin, "Senses of Proximity: Millie Chen's Immersive Environments," Art Papers 29, no. 4 (July/August 2000): 16-17; Firmin, "Sensory Navigation," n.p.

58. Crave (1993-2007) included oversized Chinese spoons arranged to replicate the tile design of the Alhambra, Granada, Spain. Chen placed spices from India, North Africa, the West Indies, and Indonesia inside the spoons. The installation combined richly coloured patterns with aromatic odours and thus appealed to the senses of smell, sight, and touch. Millie Chen, "Crave," Milliechen.com, http://milliechen. com/crave.html (accessed February 20, 2015); Jamelie Hassan, "ReOrienting Asian: Millie Chen," Fuse 18 , no. 5 (1995): 30-31.

59. Ibid., 30-31; Firmin, "Senses of Proximity," n.p.; Firmin, "Sensory Navigation," 16-17.

60 . Chen used the term "eurogirl" to refer to the image of a girl clothed in a european peasant dress and clogs. She extracted the image from a Ming style lamp that she bought as decoration for the Gladstone Hotel room. Chen used the term "genetic ball" to refer to the image of a ball containing a picture of a boy and monkey morphing one into the other. In depicting such genetic mutations, she critiqued the misguided appropriation of animals and humans in decorative motifs, including chinoiserie. Chen, interview with the author.

61. Michelle Veitch,

"Site-Specific Practices and City Renewal: The Geo-Politics of Hotel Installations in Urban Spaces" (PhD diss., Queen's University, 2010), 164-172.

62. David Meren, With Friends Like These: Entangled Nationalisms and the Canada-Quebec-France Triangle, 1944-1970 (Vancouver: UBC Press, 2012), 217-218, 221-222, 225, 234.
Taiwanese artist Michael Lin also addresses postcolonial politics and capitalist markets in his handcrafted wallpaper installations that mimic coffee shops, office spaces, skateboard ramps, and hardware stores. Recreating everyday spaces in museum settings, he facilitates critiques of institutions and establishes counter-public spheres that intervene in the consumer spectacles of the ever-increasingly industrialized and commercialized economy that has evolved out of imperial expansion schemes-including the trade, collection, and display of wallpaper designs in galleries. ${ }^{55}$

Like these artists, Millie Chen redresses diasporic histories and identities by dismantling the colonial narratives and gendered discourses embedded in decorative display, thus developing the interventionist practices underlying wallpaper installations. Art theorists Peter White and Sandra Firmin argue that Chen subverts the chinoiserie ornamental patterns created by and for European audiences. Focusing on Chen's installation Hungry Ghost Rubric (1996) at the Gairloch Galleries in Oakville, Ontario, ${ }^{56}$ White and Firmin show how Chen's explorations of repressed cultures and histories intervene in the master narratives and scientific discourses developed during periods of imperialism. ${ }^{57}$ Firmin and Jamelie Hassan similarly argue that Chen reinterpreted "orientalist" display in her project titled Crave exhibited at Yyz in Toronto (1995), and Wharf, Centre d'art contemporain de Basse-Normandie (2007). ${ }^{58}$ This latter project redefined ornamental craft by referencing cross-cultural exchange between and among Asian, Arab, and African nations, hence interrupting the epistemological and ideological discourses surrounding global travel and trade, including international exhibitions organized by various governmental and artistic institutions. ${ }^{59}$

Finally, Chen's room design titled Chinoiserie, mounted in room 417 of the Gladstone Hotel in Toronto in 2006, involved the same wallpaper as her 2007 installation at the Canadian Cultural Centre. Chen hand-painted the same figures in both exhibitions; however, at the Gladstone Hotel she added a Baluch tiger, a "eurogirl," a "genetic ball," and a CN tower hat. ${ }^{60}$ Referencing a Toronto urban landmark placed the hotel building in the context of city planning schemes, including the development of cultural corridors designed to meet the needs of expanding tourist economies and capitalist markets. ${ }^{61}$ Through these wallpaper projects, Chen redefined chinoiserie décor, characterized as placeless and affectless due to its lack of identifiable settings and its superficial portrayal of Chinese cultures. Historical chinoiserie wallpaper patterns represent Chinese people and localities as indistinguishable from each other, and thus homogenize complex regional politics and economies. Intervening in essentialist and traditionalist readings of interior décor, Chen uses techniques of parody and satire to represent transnational cultures and histories, thus interrogating "orientalist" stereotypes embedded in ornamental displays.

Reinterpreting theories of place, locality and site specificity within and across cultural and tourist spaces, Chen developed critical craft practices from her earlier art projects to her Paris exhibition by interrogating the social and political meaning of the surrounding artistic and commercial complexes. It is particularly noteworthy that Chen situated her 2007 wallpaper installation at the Canadian Cultural Centre, founded in 1967 shortly after the federal government ratified a cultural accord with France. ${ }^{62}$ According to David Meren, 
63. Ibid., 213-221, 232-233.

64. Ibid., 217-218, 221-222, 225,234 .

65. Kwon, One Place AfterAnother, 31.

66. Chen, "Public Art as Process," Espace 63 (Spring 2003): 22-23.
Ottawa representatives collaborated with French institutions to co-sponsor programs in education, art, and technology in order to undermine Quebec's politics of autonomy and sovereignty that challenged policies of Canadian national unity. ${ }^{63}$ The Cultural Centre's goal of mutual exchange, however, masked tensions and conflicts at provincial and national levels surrounding an institution created to meet Ottawa's cultural diplomacy needs. ${ }^{64}$ Through cultural diplomacy, the federal government sought to develop international relations, including the political and economic exchange of resources and services, through art exhibitions, trade agreements, education programs, etc. Following this agenda, the Cultural Centre organized Chen's exhibition in collaboration with Wharf, Centre d'art contemporain de Basse-Normandie. As a Chinese-Canadian artist exhibiting at two separate venues in France, Chen negotiated the differing interests and mandates of the varied funders, administrators, and curators who operated and managed the gallery organizations. Although Chen reflected upon institutional agendas while planning and implementing her site-specific project at the Paris location, she removed Canada as a nation and territory from her work and from the geopolitical conflicts she referenced, thus neutralizing the pressures and tensions of the country's regional and national politics that contextualize its founding.

These politics follow upon a history of British and French colonialism in Canada that resulted in the relocation of Indigenous peoples to reserve lands from the eighteenth century onward, and the removal of Indigenous children from their communities to residential schools in the nineteenth and twentieth centuries. Colonialism also disenfranchised certain immigrants from the eighteenth century onward, including Chinese inhabitants who were forced to work menial jobs for low wages, were segregated into residential enclaves due to racial discrimination, and were denied the same citizenship rights as European settlers. Imperial settlement schemes thus had a significant impact on Indigenous and immigrant communities, yet this history disappears in Chen's work. While she developed a postcolonial critique that pertained to the production and consumption of ornamental design in China, France, and England, she overlooked imperial expansion in Canada and North America and the impact this had on decorative arts. It is precisely the history of migration movements, relocation schemes, and displacement processes in Canada that haunts present day policies of cultural diplomacy used to define gallery mandates at institutions such as the Canadian Cultural Centre.

The overarching organizational mandate of the Cultural Centre hides the history of Canadian colonialism and compromises practices of criticality facilitated through Chen's exhibition, raising questions about the relevancy and efficacy of craft-based, site-specific interventions. Miwon Kwon addresses such concerns in her assessment of site-specific art that becomes unhinged from museum institutions by reformulating systems of knowledge and interpretation through which critical and theoretical discourses are defined and constituted, including the political and ideological frameworks surrounding gallery programs and policies. While such discursive sites facilitate processes of institutional critique, they continue to operate in tourist markets and capitalist economies, which leads Kwon to ask if "the unhinging of 
site-specificity [is] then, a form of resistance to the ideological establishment of art, or a capitulation to the logic of capitalist expansion?" 65

This line of questioning is particularly pertinent to Millie Chen's exhibition, which exemplifies the discursive turn in craft-based, site-specific art and how that art can become unhinged from the institutional contexts in which it is produced and exhibited. In discussing her public-sited projects, Chen suggests that she extricates her installations from the organizational frameworks in which they are created by exercising a "critical sense" while negotiating the contractual and formal parameters established by gallery funders and community partners. ${ }^{66} \mathrm{Her}$ site-specific intervention at the Canadian Cultural Centre developed this strategy by engaging in light-hearted humour and subversive play to reimagine the political and cultural landscape of fantasy and folly embedded in colonialist interior décor. While Chen's exhibition subtly, but significantly, interrogated the visual and semantic field of ornamental design and thus redefined the function and meaning of the surrounding architectural site and, by extension, the gallery institution, her installation needs to be understood in relation to the Cultural Centre's mandates to fulfill federal and national agendas in compliance with its role as a subsidiary of a Canadian Embassy that facilitates the expansion and development of cultural exchange locally and internationally. Chen leaves these larger administrative and governmental mandates and policies unquestioned in her work, thus revealing the paradox of critical craft practices of site-specificity that come up against competing ideologies and discourses. These contradictory interests and objectives oftentimes work against each other and undo the very criticality underlying discursive design, putting into question the theoretical and conceptual paradigms through which contemporary decorative projects are understood and interpreted. q 